Article

\title{
Land Suitability for Sustainable Aquaculture of Rainbow Trout (Oncorhynchus mykiss) in Molinopampa (Peru) Based on RS, GIS, and AHP
}

\author{
Christian Ricardo Calle Yunis, Rolando Salas López ${ }^{\circledR}$, Segundo Manuel Oliva Cruz, \\ Elgar Barboza Castillo ${ }^{\circledR}$, Jhonsy Omar Silva López ${ }^{\circledR}$, Daniel Iliquín Trigoso and \\ Nilton B. Rojas Briceño * \\ Instituto de Investigación para el Desarrollo Sustentable de Ceja de Selva (INDES-CES) de la Universidad \\ Nacional Toribio Rodríguez de Mendoza (UNTRM), Chachapoyas 01001, Peru; calleyunis@gmail.com (C.R.C.Y.); \\ rsalas@indes-ces.edu.pe (R.S.L.); soliva@indes-ces.edu.pe (S.M.O.C.); ebarboza@indes-ces.edu.pe (E.B.C.); \\ jhonsy.silva@untrm.edu.pe (J.O.S.L.); diliquin@indes-ces.edu.pe (D.I.T.) \\ * Correspondence: nrojas@indes-ces.edu.pe; Tel.: +51-949-667-638
}

Received: 4 December 2019; Accepted: 30 December 2019; Published: 2 January 2020

check for updates

\begin{abstract}
Peruvian aquaculture, specifically trout production, has had significant growth over the past ten years. However, the establishment and expansion of small-scale aquaculture have been carried out without considering the suitability of the land. In Peru, such land suitability studies have yet to be reported. Therefore, a methodological framework is presented for inland aquaculture, which may be replicated, with the necessary complements, for the entire Fisheries and Aquaculture sector in Peru. This work modeled the suitability of land for sustainable rainbow trout aquaculture in the Molinopampa district (Peru). Fifteen key criteria (socioeconomic, environmental and physicochemical) were identified for the proper development of fish activity. These were mapped using Remote Sensing (RS) and Geographic Information Systems (GIS). The Analytical Hierarchy Process (AHP) was applied to build peer-to-peer comparison matrices and weight the importance of the criteria. The weighted overlay of maps (criteria) made it possible to determine that $4.26 \%, 23.03 \%$ and $69.73 \%$ of the territory is "very suitable", "moderately suitable" and "marginally suitable", respectively, for the development of aquaculture. The implementation of this methodology will contribute to more effective investment planning and efforts, both by the government and by private initiative.
\end{abstract}

Keywords: Amazonas; analytical hierarchy process (AHP); fish farming; geographic information system (GIS); GIS modeling; multi-criteria evaluation (MCE); remote sensing (RS); sustainable development

\section{Introduction}

In Peru, the Fisheries and Aquaculture (FandA) sector account for 2\% Gross Domestic Product (GDP) [1]. In particular, aquaculture production has grown at an average annual rate of $12 \%$, from 28,400 metric tons (MT) in 2006 to just over 100,000 MT in 2017, being rainbow trout (Oncorhynchus mykiss), prawns (Litopenaeus vannamei), fan shell (Argopecten purpuratus) and tilapia (different varieties), species which represent $97 \%$ of the total volume harvested [2]. In 2017, trout accounted for $54.63 \%(54,878.43 \mathrm{MT})$ of Peruvian aquaculture production, $88.6 \%$ of which remained in the national market, consolidating a growth of $339.1 \%$ over the last ten years [3]. However, Peruvian aquaculture still has some limitations (technological, commercial, logistics organization, access to credit, technical-professional capacity, network of service providers, and easily accessible goods) that have not allowed its expansion compared to other countries of the region such as Chile, Ecuador, Brazil, and Mexico [2,4]. In addition, one of the biggest challenges for the sustainable development 
of aquaculture is the common use of water, land and other resources with alternative uses such as fisheries, livestock, agriculture and tourism, among others [5].

To enable sustainable and competitive aquaculture, under the Ecosystem Approach to Aquaculture (EAA) [6,7], this activity must be spatially planned, including zoning, selection of suitable sites and design of aquaculture management areas [5,8]. In order to minimize as much as possible, the common problems arising from the lack of spatial and administrative planning [5,9] are: (i) fish diseases; (ii) environmental problems (eutrophication, loss of ecosystem services and biodiversity, etc.); (iii) production problems (lower growth and biomass, oxygen and microalgae overconsumption, poor product standardization, etc.); (iv) social conflicts; (v) post-harvest problems; (vi) financial risk, and; (vii) lack of resilience to climate variations and other external threats and disasters.

In this sense, remote sensing (RS), Geographic Information Systems (GIS) and the technique of Multi-criteria Evaluation (MCE) integration are recognized as a decision support system which integrates spatially referenced data in a space-referenced environment decision-making problem, which often include a large set of viable alternatives $[5,10]$. An MCE technique that has been used to describe, explain, and predict suitable sites under criteria of interest is the Analytical Hierarchy Process (AHP) [10]. The AHP reduces subjectivity in decision-making by creating a series of filters (hierarchies) of selection and at the same time, it allows the choice between complex alternatives [11].

The tools RS, GIS, and MCE have allowed studies of land suitability evaluation for inland aquaculture (lentics and lotics). The entire territory of Africa [12], Latin America [13], Uruguay [14], Colombia [15] and other regions of smaller geographical extent [10,16-26] has been evaluated. In Peru, no similar studies have been reported, and aquaculture in land-ponds becomes more important since insurance permits for inland aquaculture production are easily taken by smallholder farmers, who belong to the Limited Resource Aquaculture (AREL; 62.3\%) and Micro and Small Business (AMYPE; $37.5 \%$ ) [27]. In summary, they guarantee the livelihoods of just over $1 \%$ of the Peruvian population [2], contribute to food security (increased consumption of animal protein and improvement of nutritional levels), and help to alleviate poverty [10]. However, the establishment and expansion of small-scale aquaculture have been performed without regard to the suitability of the site in terms of land, water, supplies, socio-economics, and other resources available for aquaculture development [19].

Given the importance of aquaculture and the limitations of land suitability assessments for fish farming, this study has likewise integrated RS, GIS, and AHP with the aim of modeling land suitability for sustainable rainbow trout aquaculture in the Molinopampa district in Peru. Consequently, (a) key criteria (socio-economic, environmental and physicochemical of water sources) for the proper development of fish activity were identified and mapped; (b) the importance of criteria and sub-criteria was hierarchized and weighted by peer-to-peer comparison matrices, and; (c) potential sites were determined for the development of the activity. Finally, it seeks to provide tools for the decision-making process in the allocation of land for aquaculture in the district, furthermore, to present a methodological framework in inland aquaculture, which may be replicated, with the necessary complements, for the entire FandA sector in Peru.

\section{Materials and Methods}

\subsection{Study Area}

The district of Molinopampa covers approximately an area of $340.64 \mathrm{~km}^{2}$ and is located southeast of the region of Amazonas (Peru) (Figure 1). It is located between the $6.13^{\circ}$ and $6.31^{\circ}$ South-latitude parallels and the meridians $77.47^{\circ}$ and $77.73^{\circ}$ West longitude, with an altitude gradient between 2000 and 3700 m.a.s.l. It has a very humid climate, both warm temperate and cold temperate, with minimum temperatures reaching $7{ }^{\circ} \mathrm{C}$ and maximum temperatures of $25^{\circ} \mathrm{C}$. The average annual cumulative precipitation is $1560 \mathrm{~mm}$, the months from November to March have the most rainfall intensity [28]. The population in the study area amounts to 2176 inhabitants, with a population density of 6.52 inhabitants $/ \mathrm{km}^{2}$ and about $80 \%$ dedicated to agricultural and forestry activity [29]. 


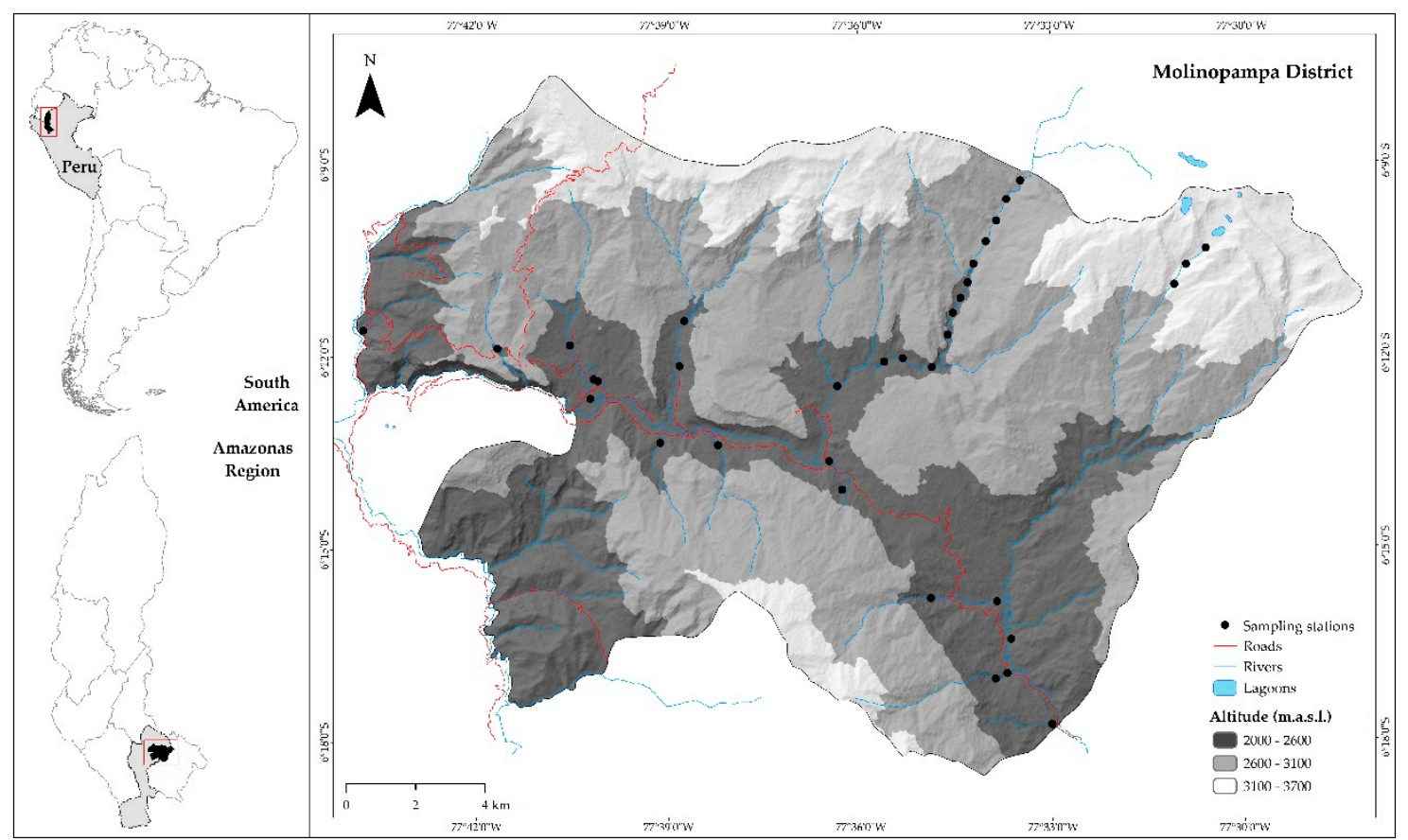

Figure 1. Geographical location of Molinopampa district, Chachapoyas province-Amazonas, Peru.

The district is characterized by small-scale agriculture as well as one of the four main dairy cattle fronts in Amazonas [30]. However, poor agricultural practices, unsustainable forestry and the rearing of cattle, first and foremost in the open or extensive field [31], with a low technological and strategic level of grass production and management, have led to the soil degradation [32]. As alternatives, silvopastoral technologies have been adopted, driven by genetic improvement through artificial insemination, built facilities for milking and proper handling of raw milk [33]. The Private Conservation Area (PCA) Palm Forest of the rural community of Taulía Molinopampa $\left(109.2 \mathrm{~km}^{2}\right)$ [34] has also been established, a unique ecosystem of palm trees of the genus Ceroxylon sp. where productive anthropic activities are restricted. In addition, to promote aquaculture, the Regional Directorate of Amazon Production (DIREPRO-A) of the Ministry of Production (PRODUCE) has installed the experimental and production center for rainbow trout.

Currently, only five families supplement their family economy with aquaculture in earthen ponds. However, in the last two years, fish activity has been enhanced by the hydrological potential and increased active promotion of the national government. This promotion has been given through the co-financing of RandD+i projects by the National Programme of Innovation in Fisheries and Aquaculture (PNIPA) of PRODUCE and implemented in partnership between the academy and local producer associations. PNIPA has been provided with government grant funding to co-finance RandD+i projects in PandA that promote applied, adaptive, extensionism, and capacity-development of the service offering [1]. As a result of the PNIPA 2017-2018 and part of 2018-2019, grants have been awarded for 470 projects in aquaculture, of which the department of Amazonas concentrates 49 $(10.4 \%)$, executing six of them in Molinopampa district with an investment of more than 300 thousand dollars (USD) [35].

\subsection{Methodological Design}

Figure 2 shows the flowchart made for modeling land suitability for sustainable rainbow trout aquaculture in the Molinopampa district. In summary, the criteria that determine the activity, which was mapped using RS and GIS, were identified and selected and compared to each other to determine their degree of importance through the AHP. Thereafter, in a GIS environment, the reclassified maps were integrated according to suitability thresholds using the weighted overlay. 


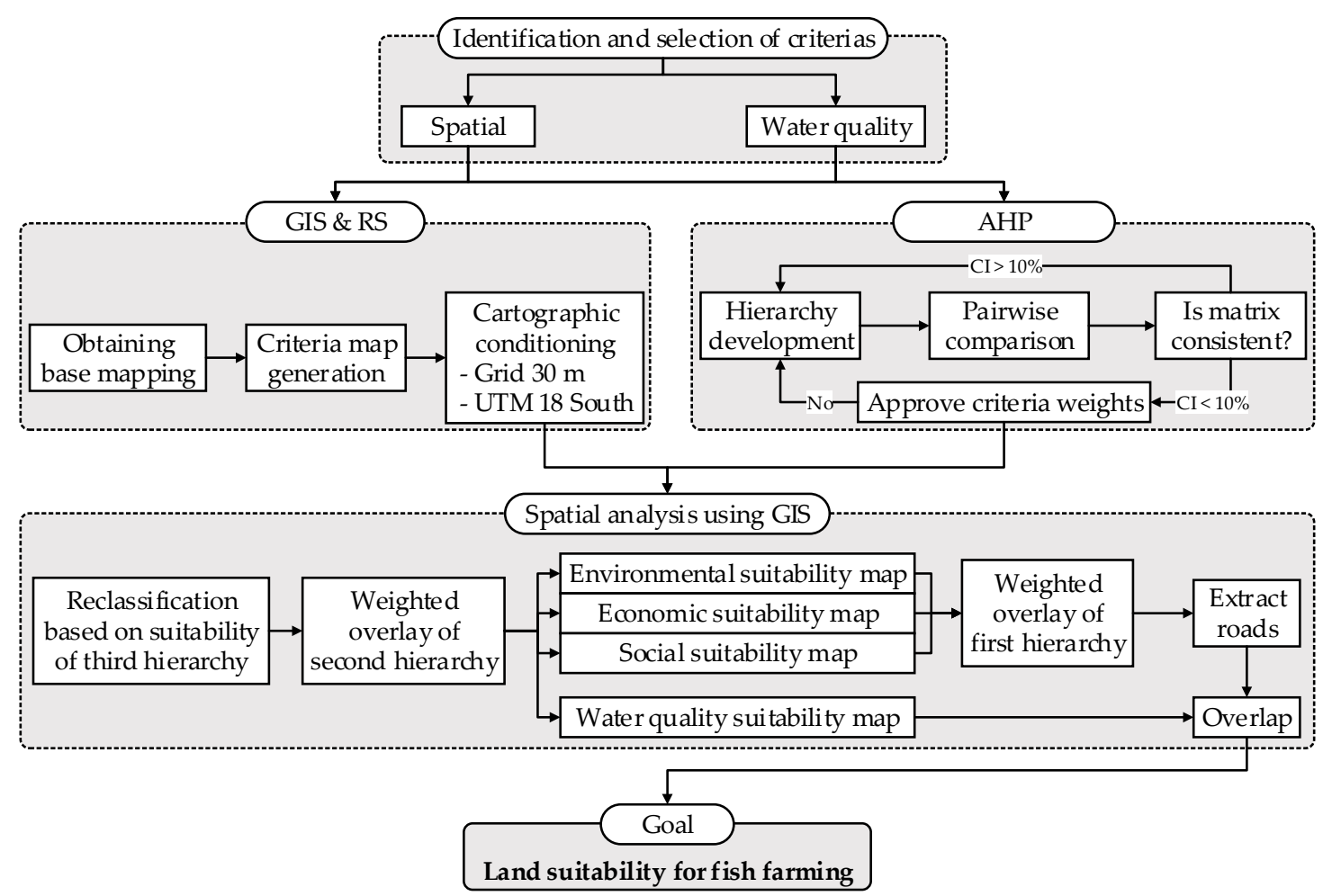

Figure 2. Flowchart of the methodology to model the suitability of the land for aquaculture (rainbow trout) in the district of Molinopampa (Peru).

\subsection{Criteria Identification}

The identification of the potential area for aquaculture should be based on favorable criteria to allow the growth of species of interest [5]. These criteria were established by considering rainbow trout breeding manuals from Peru [36] and FAO [37], land suitability studies for rainbow trout aquaculture $[17,18]$, aquaculture of other species $[8,16,19,24-26]$, and the criteria for aquaculture zoning set by the FAO $[5,13]$. The same ones that were validated for the planning process by a group of experts, made up of five fish farmers in the study area and six aquaculture specialists from the DIREPRO-A of the PRODUCE. Based on the availability of data and the biophysical and socio-economic conditions of the study area, a hierarchy was built, comprised of the objective (land suitability for aquaculture), two sub-objectives (spatial suitability and water quality), four criteria (environmental, economic, social, and physicochemical) and 15 sub-criteria (terrain slope, land cover/land use, clay content of soil, $\mathrm{pH}$ of soil, distance to rivers, distance to roads, distance to markets, distance to inputs, distance to populations, protected areas and $\mathrm{pH}$, dissolved oxygen, temperature, alkalinity, and hardness of water) (Figure 3).

The sub-objectives (Figure 3) meet the type of GIS data model that enabled its suitability analysis, the raster model for continuous spatial sub-criteria (spatial suitability) and vector model for point vector character sub-criteria (34 sampling stations for water quality suitability).

\subsection{Software, Base Mapping and Satellite Imagery}

In recent years, the use of open-source software has received substantial attention in the development of studies applied to spatial analysis. It is suggested to use it in science to ensure reproducibility, reliability, security, interoperability, and rapid deployment of information [38]. Therefore, the management and processing of spatial data were carried out in the open-source QGIS software (see 2.18.28) and its plugins. While primary and secondary data (biophysical and socioeconomic) were collected through social surveys, analysis of official documents, national and international data, and field measurements. 


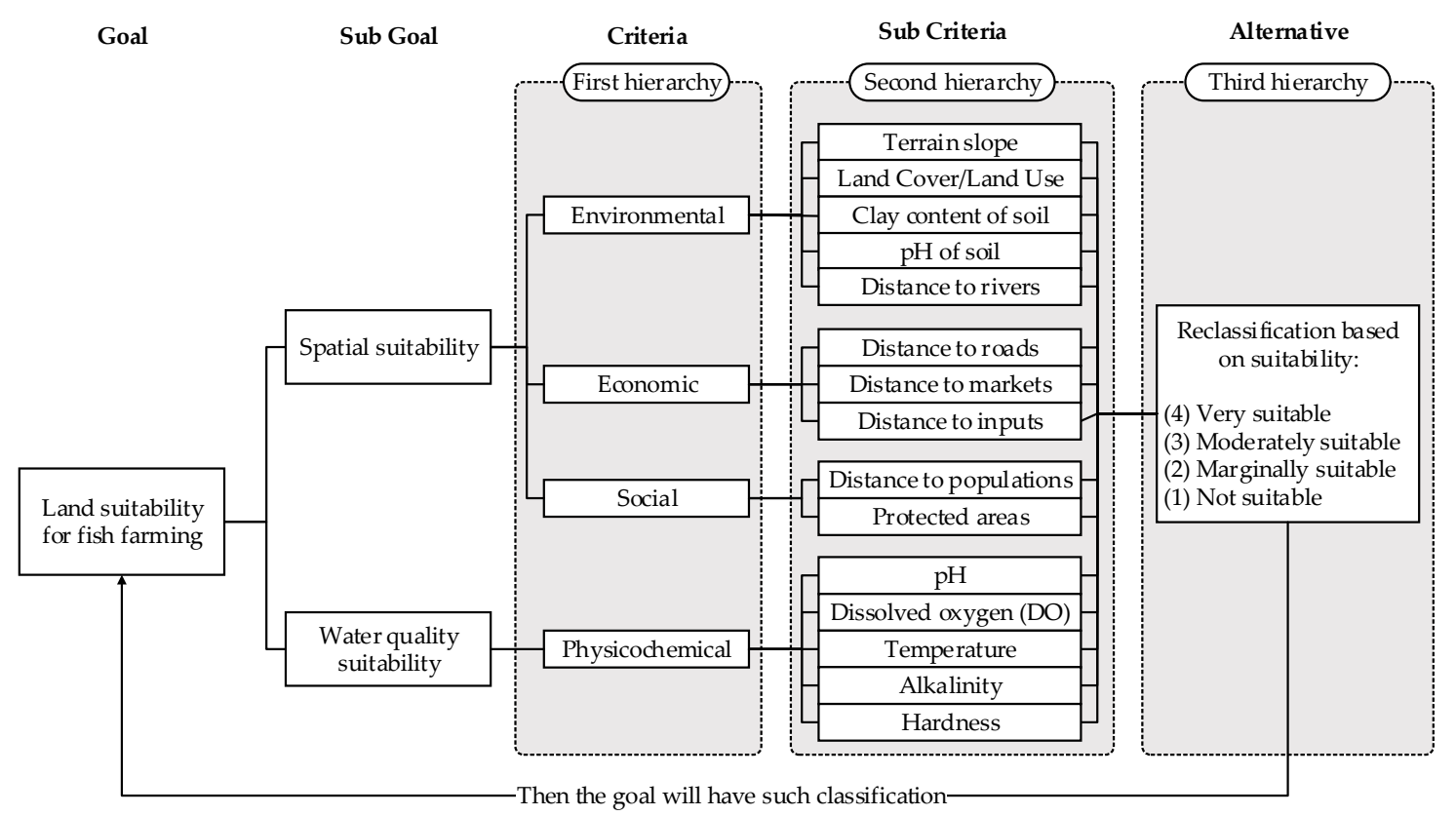

Figure 3. Hierarchy of criteria for modeling land suitability for aquaculture (rainbow trout) in the district of Molinopampa (Peru).

The slope of the land was obtained from the Global Digital Elevation Model (GDEM; ver. 3; band C; resolution: $30 \mathrm{~m}$ ), it was generated based on data from the Shuttle Radar Topography Mission (SRTM) [39]. The GDEM was downloaded from the United States Geological Survey (USGS) database, through QGIS' SRTM Downloader add-on.

A Sentinel 2A satellite image (Path/Row: 17MRP; 2 August 2019; Bands: 2-8A, 11-12) acquired from the European Space Agency's (ESA) Copernicus Services Data Hub platform, was used to develop a map of Land Cover and Land Use (LC/LU), through QGIS' Semi-Automatic Classification Plugin (SCP) [40]. The digital processing of the image was carried out following the methodology of Rojas et al. [41] at the SCP. Based on the CORINE Land Cover methodology adapted for Peru [42], prior knowledge of the study area and 68 training areas, 6 classes of LC/LU were ranked: artificialized area, scrubland and grassland, shrub vegetation, grass and crops, waterbody, and forests. Classification reliability is recognized as good [43], since the confusion matrix based on 196 checkpoints [44] indicated a Global Accuracy and Kappa Index of 0.88 and 0.76 , respectively.

In addition, to have a reference to the distribution of roads, rivers, and populations of the district, the road network of the Ministry of Transport and Communications (MTC) [45], the hydrography of Sheet $13 \mathrm{~h}$ of the National Charter of the National Geographical Institute (IGN) (scale 1:100,000), and populated centers downloaded from the Ministry of Education web portal (MINEDU) [46] were used. These vector layers were updated and complemented by field tours and satellite imagery in Google Earth Pro (see 7.3.2.5776) and SAS Planet (see 190707) [47,48]. The sales markets and sources of aquaculture supplies were georeferenced in accordance with expert group considerations, through a Garmin Montana 680 GPS receiver. Proximity (to rivers, roads, populated centers, markets, and input sources) was mapped using the Euclidean Distance tool.

To assess the physicochemical quality of water, 34 water sampling stations (SS) were established (Figure 1) in the main riverbeds and where aquaculture is currently practiced. Fieldwork was conducted on 20 June 2019 (the dry season). The temperature, $\mathrm{pH}$, and dissolved oxygen were recorded on-site using a Hach HQ40D portable multiparameter meter. For the alkalinity and hardness studies, 34 water samples were collected, transported, and analyzed under the standards set by the Soil and Water Research Laboratory (LABISAG) of the Research Institute for the Sustainable Development of the Jungle brow zone (INDES-CES) of the National University Toribio Rodríguez de Mendoza (UNTRM). 
The clay content and the $\mathrm{pH}$ of the soil at one-meter depth were obtained from SoilGrids (see 0.5.3). This system provides global predictions for the standard numerical properties of the soil at seven depths and $250 \mathrm{~m}$ resolution, generated from 150,000 soil profiles, 158 covariates obtained from remote sensors and a set of machine learning methods [49].

The geographical boundary of the PCA Palm Forest of the Taulía Molinopampa Rural Community was obtained from the National Service of Natural Areas Protected by the State [50]. Experts considered this sub-criterion as a slight restriction on fish activity.

In summary, 10 base layers were prepared in a raster model, one thematic map for each sub-criterion of spatial suitability. These were standardized at a spatial resolution of $30 \mathrm{~m}$, in the WGS 1984 UTM 18 South coordinate system and spatial boundaries restricted to a $30 \mathrm{~m}$ buffer of the district's political geographic boundaries. Moreover, a vector model base layer was prepared, corresponding to the suitability of water quality. This point-type vector layer contained in the attribute table one field for each sub-criterion (physico-chemical parameter of water).

\subsection{Multi-Criteria Evaluation (MCE) and Analytic Hierarchy Process (AHP)}

Conflicting multi-goal and criteria decision-making situations can be solved using the AHP technique [51]. In AHP, the problem is structured hierarchically (Figure 3) at different levels comprising a predetermined number of elements [24].

\subsubsection{Suitability Sub-Criteria Thresholds}

To develop the third hierarchy (Figure 3), the criteria were reclassified and scored on a categorical scale of four levels of suitability [16,19,25]: "Very suitable" (4), "Moderately suitable" (3), "Marginally suitable" (2), and "Not suitable" (1). This stage was based on bibliographic review and consultation with an expert group to adapt the suitability thresholds for each sub-criterion to the local environmental condition [5] (Table 1).

Table 1. Reclassification and scoring of the third hierarchy of criteria to model the suitability of land for aquaculture (rainbow trout) in the district of Molinopampa (Peru).

\begin{tabular}{|c|c|c|c|c|c|}
\hline Criteria/Sub Criteria & $\begin{array}{l}\text { Very Suitable } \\
\text { (4) }\end{array}$ & $\begin{array}{l}\text { Moderately } \\
\text { Suitable (3) }\end{array}$ & $\begin{array}{l}\text { Marginally } \\
\text { Suitable (2) }\end{array}$ & $\begin{array}{l}\text { Not Suitable } \\
\text { (1) }\end{array}$ & References \\
\hline \multicolumn{6}{|c|}{ Environmental } \\
\hline Land Cover/Land Use & $\begin{array}{l}\text { Grass and } \\
\text { Crops }\end{array}$ & $\begin{array}{c}\text { Shrub } \\
\text { Vegetation }\end{array}$ & $\begin{array}{l}\text { Forest } \\
\text { Grassland } \\
\text { Scrubland }\end{array}$ & $\begin{array}{l}\text { Artificialized } \\
\text { Area }\end{array}$ & $\begin{array}{l}\text { Adapted from } \\
{[8,16-18,26]}\end{array}$ \\
\hline Terrain slope (\%) & $<5$ & $5-15$ & $15-25$ & $>25$ & Adapted from $[8,16]$ \\
\hline Clay content of soil (\%) & $30-40$ & $40-60$ & $25-30$ & $<25$ & Adapted from $[8,25]$ \\
\hline $\mathrm{pH}$ of soil & $6.5-8.5$ & $5.5-6.5$ & $4.0-5.5$ & $\leq 4.0 / \geq 8.5$ & Adapted from $[13,19]$ \\
\hline Distance to rivers $(\mathrm{km})$ & $<0.5$ & $0.5-1$ & $1-1.5$ & $>1.5$ & Adapted from $[8,18,26]$ \\
\hline \multicolumn{6}{|c|}{ Economic } \\
\hline Distance to roads $(\mathrm{km})$ & $<0.5$ & $0.5-1$ & $1-1.5$ & $>1.5$ & Adapted from $[8,18,26]$ \\
\hline Distance to markets (km) & $<2$ & $2-5$ & $5-8$ & $>8$ & Adapted from [19] \\
\hline Distance to inputs $(\mathrm{km})$ & $<2$ & $2-5$ & $5-8$ & $>8$ & Adapted from [19] \\
\hline \multicolumn{6}{|c|}{ Social } \\
\hline $\begin{array}{l}\text { Distance to populations } \\
\qquad(\mathrm{km})\end{array}$ & $<0.5$ & $0.5-1$ & $1-1.5$ & $>1.5$ & Adapted from $[8,26]$ \\
\hline Protected areas & Outside & - & Inside & - & Adapted from [24] \\
\hline \multicolumn{6}{|c|}{ Physicochemical quality water } \\
\hline $\mathrm{pH}$ & $6.6-7.9$ & $5.1-6.5 / 8-8.5$ & $4.0-5.0 / 8.6-9.5$ & $\leq 4.0 / \geq 9.5$ & \\
\hline Dissolved oxygen (mg/L) & $6.0-8.5$ & $4.5-6 / 8.5-9.0$ & $3.0-4.5 / 9.0-10.0$ & $\leq 3.0 / \geq 10.1$ & \\
\hline Temperature $\left({ }^{\circ} \mathrm{C}\right)$ & $9.0-14.5$ & $4.5-9.0 / 14.5-16.5$ & $3.0-4.5 / 16.5-20.0$ & $\leq 3.0 / \geq 20.0$ & Adapted from \\
\hline Alkalinity (ppm CaCO3) & $80-180$ & $50-80 / 180-230$ & $30-50 / 230-280$ & $\leq 30 / \geq 330$ & \\
\hline Hardness (ppm CaCO3) & $60-300$ & $40-60 / 300-350$ & $20-40 / 350-400$ & $\leq 20 / \geq 400$ & \\
\hline
\end{tabular}

Thematic maps of each sub-criterion were reclassified using QGIS according to the thresholds set out in Table 1. The raster reclassification was based on the assignment of scores (from 1 to 4 ) to each 
pixel, in the vector model, new fields were created in the attributed table, where the suitability score was placed for each sub-criterion. Figure 4 illustrates the suitability reclassification of each sub-criterion.

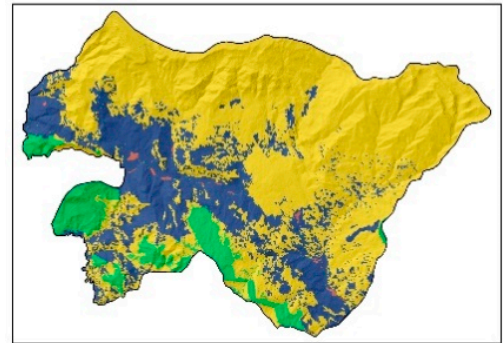

(a) Land Cover/ Land Use

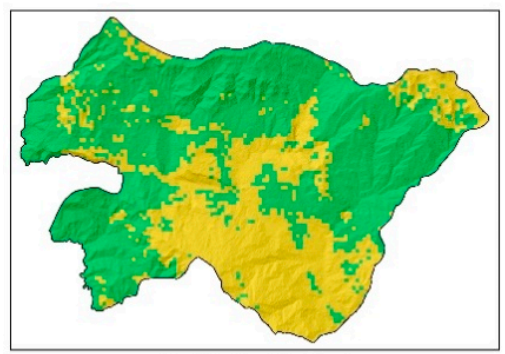

(d) $\mathrm{pH}$ of soil (at $1 \mathrm{~m}$ )

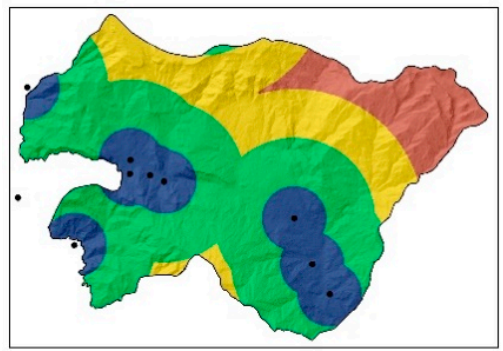

(g) Distance to markets

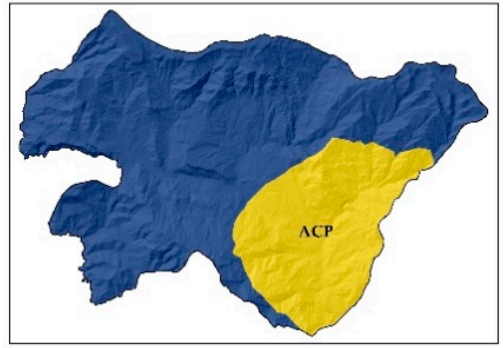

(j) Protected areas

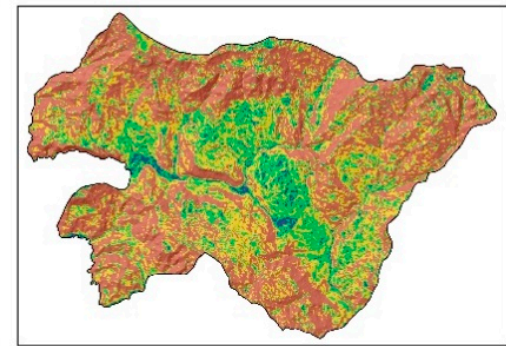

(b) Terrain slope

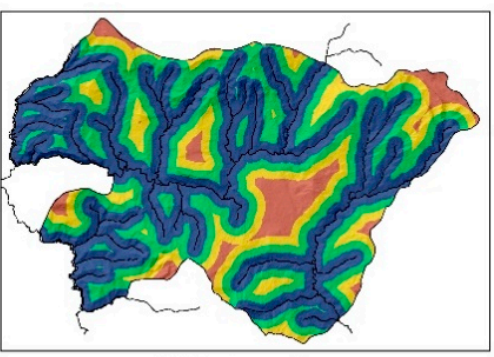

(e) Distance to rivers

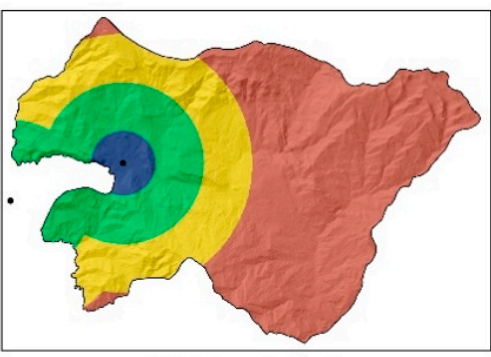

(h) Distance to inputs

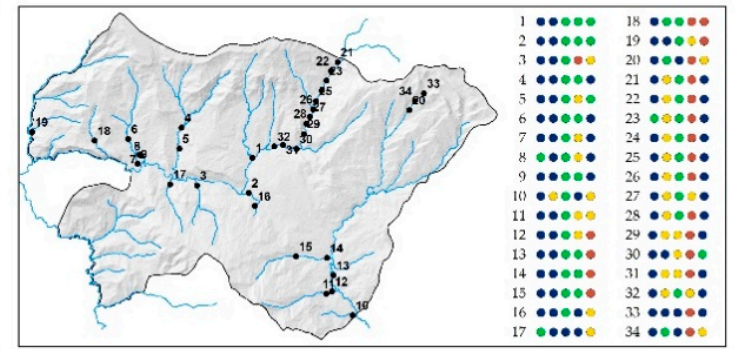

(k) Dissolved oxygen; pH; Temperature; Alkalinity; Hardness

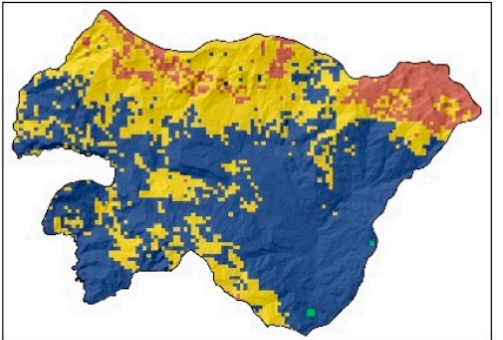

(c) Clay content of soil (at $1 \mathrm{~m}$ )

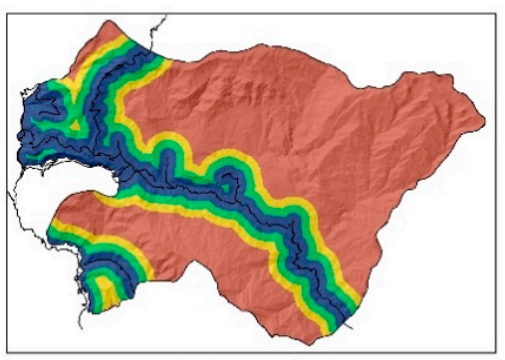

(f) Distance to roads

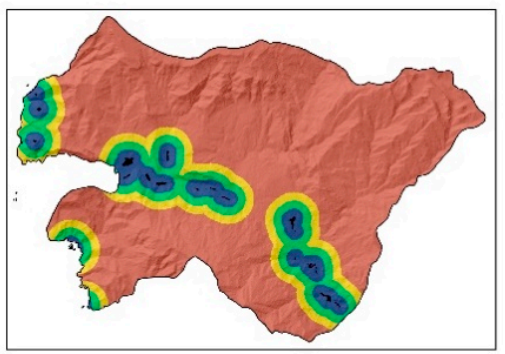

(i) Distance to populations

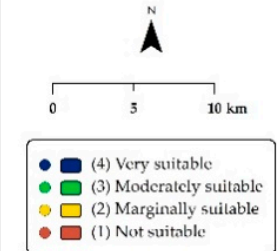

Figure 4. Reclassification and scoring of the third hierarchy of criteria to model the suitability of land for aquaculture (rainbow trout) in the district of Molinopampa (Peru).

\subsubsection{Determination the Weight of Importance}

To establish the first and the second hierarchy, Peer Comparison Matrixes (PCMs) were built. These allow the comparison of one criterion to others and establish a degree of importance to each other [52]. The comparison was based on the nine-level scale proposed by Saaty [53] (Table 2), where each of the six members of the expert group assigned a value judgment, from the least to most important, based on their experience and local reality. Each specialist completed four PCMs at the sub-criteria level and one at the criterion level, according to the hierarchical group structure indicated in Figure 3.

The square PCMs developed by the specialists (Tables S1-S5) were complemented by columns comprising the stages of standardization, prioritization (standardization of criteria), and matrix 
consistency check calculations [54]. Prioritization allows us to obtain the Weight of Importance of each sub-criterion and criterion, where the sum of the weights must be equal to 1 per hierarchical group [55]. In the development of square PCMs, researchers' subjective preferences can lead to inconsistencies in prioritization [16]. Therefore, to define the acceptable value for this inconsistency, the Consistency Ratio (CR) [56] was calculated. $C R$ is calculated by comparing the Consistency Index $(C I)$ of the matrix in question with a Random Consistency Index (RI) [57] (Equation (1)). This RI is defined according to the number of criteria $(n)$ [58] (Table 3 ) and $C I$ depends on the largest or main own value of the matrix ( $\lambda$ max) and $n$ (Equation 2).

$$
\begin{gathered}
C R=C I / R I, \\
C I=(\lambda \max -n) /(n-1),
\end{gathered}
$$

Table 2. Scale established for the allocation of value judgments in Peer Comparison Matrices (PCM).

\begin{tabular}{ccccccccc}
\hline $1 / 9$ & $1 / 7$ & $1 / 5$ & $1 / 3$ & 1 & 3 & 5 & 7 & 9 \\
\hline \multirow{2}{*}{ Extreme } & Strong & Moderate & \multirow{2}{*}{ Equal importance } & Moderate & Strong & Extreme \\
\cline { 6 - 7 } \cline { 5 - 7 } & & & \multicolumn{3}{c}{ Most important } \\
\hline
\end{tabular}

Table 3. Random Index $(R I)$ to determine the Consistency Ratio $(C R)$ of Peer Comparison Matrices (PCM).

\begin{tabular}{ccccccccccccccccc}
\hline $\mathrm{n}$ & 1 & 2 & 3 & 4 & 5 & 6 & 7 & 8 & 9 & 10 & 11 & 12 & 13 & 14 & 15 & 16 \\
\hline $\mathrm{RI}$ & 0 & 0 & 0.525 & 0.882 & 1.115 & 1.252 & 1.341 & 1.404 & 1.452 & 1.484 & 1.513 & 1.535 & 1.555 & 1.570 & 1.583 & 1.595 \\
\hline
\end{tabular}

\subsection{Thematic Map Overlay}

The reclassified thematic maps for each sub-criterion (Figure 4) were integrated according to the hierarchical group (Figure 3) using the weighted overlay in QGIS. The Easy AHP plugin integrated the raster layers according to Equation (3) [20], depending on the pixel score of the reclassified map (GRIDi) and the weight of importance (WEIGHTi) of the sub-criterion. The integration by the hierarchical group of sub-criteria generated the sub-models of environmental, economic, and social suitability, and the integration of these generated the spatial suitability model.

$$
\text { GRIDresult }=\Sigma[(G R I D i)(\text { WEIGHTi) }],
$$

On the other hand, the physicochemical suitability sub-model, also known as the suitability model of water quality, was generated by algebraic operations in the field calculator, because this is a vector data model. The principle of Equation (3) was followed, where the GRIDi value of the raster was replaced by the field of the attribute table that contained this value.

\section{Results}

\subsection{Peer Comparison Matrix AHP}

Thirty peer-to-peer comparison matrices (Tables S1-S5), four at the sub-criteria level and one at the criterion level were built, for each of the six aquaculture specialists in the expert group. Table 4 indicates the average of the weight of importance of the criteria and sub-criteria. These were standardized and scored based on their influence on the success of small-scale aquaculture, mainly for rainbow trout in the Molinopampa district.

In line with the AHP technique; the distance to rivers (37.95\%), roads (53.49\%), and populations $(78.89 \%)$, were the most important sub-criteria in conformity with the environmental, economic, and social hierarchical groups, respectively. In turn, the economic criterion $(44.57 \%)$, followed by the environmental criterion ( $43.31 \%$ ), were the most important to determine the spatial suitability of aquaculture in the Molinopampa district. By contrast, regarding water quality suitability, 
the temperature was the most important sub-criterion (38.33\%), followed by $\mathrm{pH}(27.27 \%)$ and dissolved oxygen $(21.59 \%)$.

Table 4. Weights of importance (\%) for the second and third hierarchy of criteria to model the suitability of the land for aquaculture (rainbow trout) in the district of Molinopampa (Peru).

\begin{tabular}{|c|c|c|c|c|c|c|c|}
\hline Goal & $\begin{array}{c}\text { Main } \\
\text { Criteria }\end{array}$ & Criteria & Weight & Ranking & Sub-Criteria & Weight & Ranking \\
\hline \multirow{15}{*}{$\begin{array}{l}\text { Land suitability } \\
\text { for aquaculture }\end{array}$} & \multirow{10}{*}{$\begin{array}{c}\text { Spatial } \\
\text { suitability }\end{array}$} & \multirow{5}{*}{ Environmental } & \multirow{5}{*}{43.31} & \multirow{5}{*}{2} & Land Cover/Land Use & 11.24 & 4 \\
\hline & & & & & Terrain slope & 31.28 & 2 \\
\hline & & & & & Clay content of soil & 12.88 & 3 \\
\hline & & & & & $\mathrm{pH}$ of soil & 06.65 & 5 \\
\hline & & & & & Distance to rivers & 37.95 & 1 \\
\hline & & \multirow{3}{*}{ Economic } & \multirow{3}{*}{44.57} & \multirow{3}{*}{1} & Distance to roads & 53.49 & 1 \\
\hline & & & & & Distance to markets & 30.65 & 2 \\
\hline & & & & & Distance to inputs & 15.86 & 3 \\
\hline & & \multirow{2}{*}{ Social } & \multirow{2}{*}{12.12} & \multirow{2}{*}{3} & Distance to populations & 78.89 & 1 \\
\hline & & & & & Protected areas & 21.11 & 2 \\
\hline & \multirow{5}{*}{$\begin{array}{c}\text { Water } \\
\text { quality } \\
\text { suitability }\end{array}$} & \multirow{5}{*}{ Physicochemical } & & & $\mathrm{pH}$ & 27.27 & 2 \\
\hline & & & & & Dissolved oxygen & 21.59 & 3 \\
\hline & & & & & Temperature & 38.33 & 1 \\
\hline & & & & & Alkalinity & 6.97 & 4 \\
\hline & & & & & Hardness & 5.83 & 5 \\
\hline
\end{tabular}

The average $\mathrm{CR}$ for each hierarchical group of criteria evaluated in the weighting of the $30 \mathrm{PCMs}$ (Tables S1-S5) ranged from 0.0275 to 0.0812 (Table 5), within the established CR $(<0.10)$ to be considered as consistent and acceptable matrices. This results in a low probability that the weights have been set by chance. When evaluating the consistency of a two-parameter matrix, the RI assumes a value of 0 (Table 3), which does not allow Equation (1) to be solved, therefore, it is assumed as a consistent and acceptable matrix. This was the case with the matrix of social sub-criteria.

Table 5. Consistency ratios of the Peer Comparison Matrices (PCM) of criteria to model the suitability of land for aquaculture (rainbow trout) in the district of Molinopampa (Peru).

\begin{tabular}{cccccc}
\hline Ratio & $\begin{array}{c}\text { Environmental } \\
\text { Sub-Criteria }\end{array}$ & $\begin{array}{c}\text { Economic } \\
\text { Sub-Criteria }\end{array}$ & Social Sub-Criteria & $\begin{array}{c}\text { Physicochemical } \\
\text { Sub-Criteria }\end{array}$ & $\begin{array}{c}\text { Spatial Suitability } \\
\text { Criteria }\end{array}$ \\
\hline$n$ & 5 & 3 & 2 & 5 & 3 \\
$R I$ & 1.115 & 0.525 & 0.00 & 1.115 & 0.525 \\
$\lambda \max$ & 5.3305 & 3.0289 & - & 5.3620 & 3.0444 \\
$C I$ & 0.0826 & 0.0145 & Consistent and acceptable & 0.0905 & 0.0222 \\
$C R$ & 0.0741 & 0.0275 & 0812 & 0.0423 \\
\hline
\end{tabular}

\subsection{Suitability Sub-Models for Aquaculture in Molinopampa.}

Land suitability according to sub-criteria and criteria (now sub-models) of spatial suitability, in four levels of suitability, is indicated in Table 6 . The results of the weighted overlap of sub-criteria suitability maps for each sub-model are illustrated in Figure 5a-c. From the highest to the lowest, the economic sub-model $(9.20 \%)$, followed by social (6.35\%), and the environment $(3.92 \%)$, have the most extensive "very suitable" areas for aquaculture in Molinopampa.

The suitability of sampling stations (SS) according to sub-criteria and criterion (sub-model) of water quality suitability, in four appropriate groups, is indicated in Table 7 . The results of the weighted overlap of the fields in the attribute table of the point-type vector that contained the suitability of each sub-criterion (physicochemical parameter) are illustrated in Figure $5 \mathrm{~d}$. This sub-model, at the same time, represents the model of the suitability of water quality, since it was only evaluated in one criterion (physicochemical). 
The most important sub-criterion (temperature) is the second to have less SS "very suitable" for aquaculture. Alkalinity (15) and hardness (6) are the only sub-criteria that have SS with "not suitable" punctuation. However, it is not reflected in the sub-model because of its low weight of importance (Table 4). At the sub-model level, 17.65\% (6) and 76.47\% (26) SS are "very suitable" and "marginally suitable", respectively.

Table 6. Areas of spatial suitability according to suitability levels by criteria (sub-models) and sub-criteria for aquaculture in Molinopampa.

\begin{tabular}{|c|c|c|c|c|c|c|c|c|}
\hline \multirow[t]{2}{*}{ Criteria/Sub-Criteria } & \multicolumn{2}{|c|}{ Very Suitable } & \multicolumn{2}{|c|}{$\begin{array}{l}\text { Moderately } \\
\text { Suitable }\end{array}$} & \multicolumn{2}{|c|}{$\begin{array}{c}\text { Marginally } \\
\text { Suitable }\end{array}$} & \multicolumn{2}{|c|}{ Not Suitable } \\
\hline & $\mathrm{km}^{2}$ & $\%$ & $\mathrm{~km}^{2}$ & $\%$ & $\mathrm{~km}^{2}$ & $\%$ & $\mathrm{~km}^{2}$ & $\%$ \\
\hline Environmental & 13.34 & 3.92 & 183.49 & 53.87 & 138.30 & 40.60 & 5.51 & 1.62 \\
\hline Land Cover/Land Use & 84.97 & 24.94 & 27.70 & 8.13 & 226.89 & 66.60 & 1.08 & 0.32 \\
\hline Terrain slope (\%) & 8.90 & 2.61 & 67.06 & 19.69 & 99.05 & 29.08 & 165.64 & 48.63 \\
\hline Clay content of soil (\%) & 192.08 & 56.39 & 0.28 & 0.08 & 116.85 & 34.30 & 31.44 & 9.23 \\
\hline $\mathrm{pH}$ of soil & 0.00 & 0.00 & 214.46 & 62.96 & 126.19 & 37.04 & 0.00 & 0.00 \\
\hline Distance to rivers $(\mathrm{km})$ & 166.10 & 48.76 & 100.90 & 29.62 & 49.64 & 14.57 & 24.00 & 7.05 \\
\hline Economic & 31.35 & 9.20 & 74.36 & 21.83 & 123.78 & 36.34 & 111.16 & 32.63 \\
\hline Distance to roads $(\mathrm{km})$ & 60.06 & 17.63 & 40.48 & 11.88 & 33.57 & 9.85 & 206.54 & 60.63 \\
\hline Distance to markets $(\mathrm{km})$ & 64.19 & 18.84 & 154.91 & 45.48 & 81.39 & 23.89 & 40.15 & 11.79 \\
\hline Distance to inputs (km) & 10.85 & 3.19 & 67.38 & 19.78 & 83.19 & 24.42 & 179.22 & 52.61 \\
\hline Social & 21.62 & 6.35 & 29.75 & 8.73 & 231.23 & 67.88 & 58.05 & 17.04 \\
\hline Distance to populations $(\mathrm{km})$ & 21.62 & 6.35 & 29.75 & 8.73 & 29.24 & 8.58 & 260.04 & 76.34 \\
\hline Protected areas & 254.51 & 74.71 & 0.00 & 0.00 & 86.14 & 25.29 & 0.00 & 0.00 \\
\hline
\end{tabular}

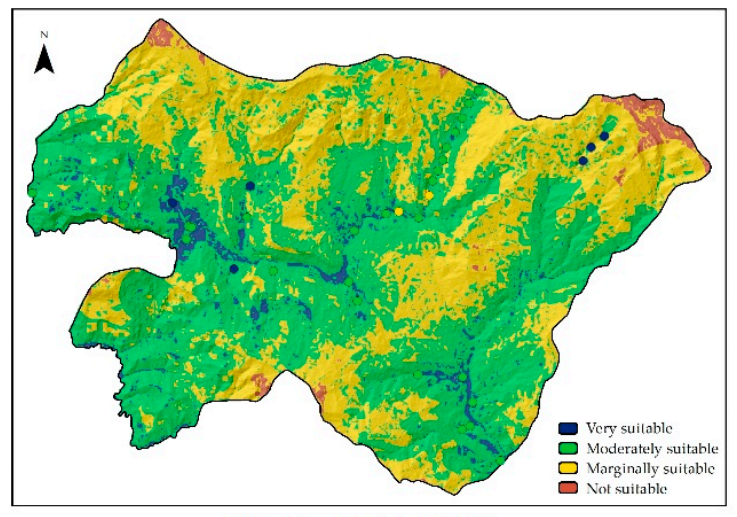

(a) Environmental suitability

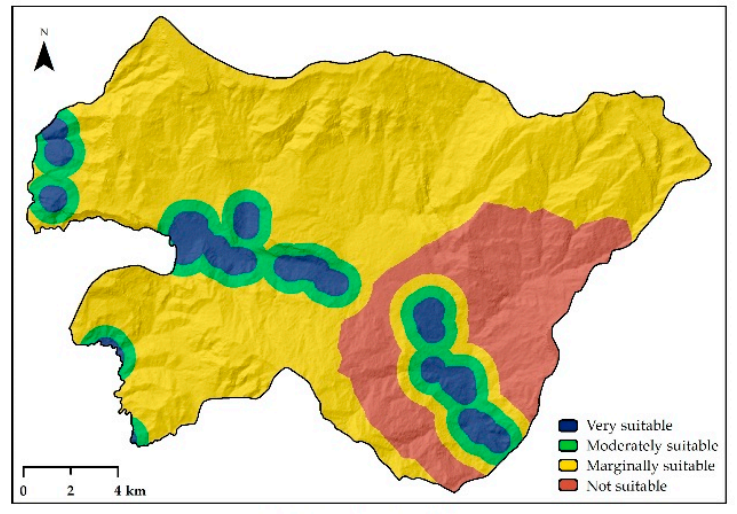

(c) Social suitability

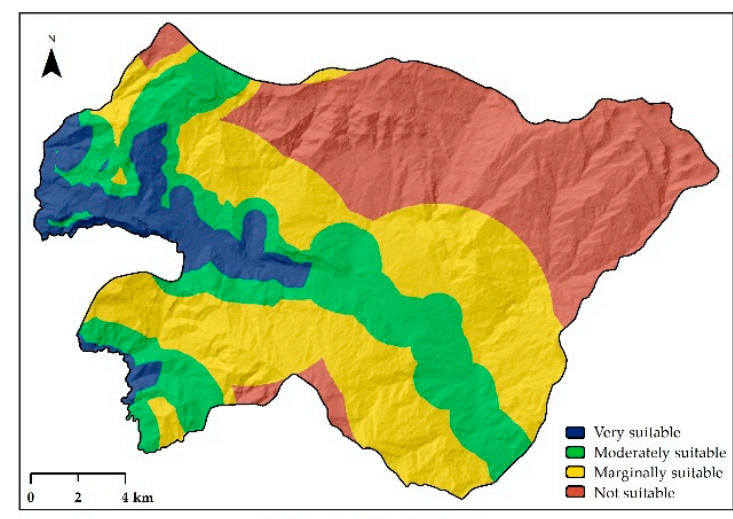

(b) Economic suitability

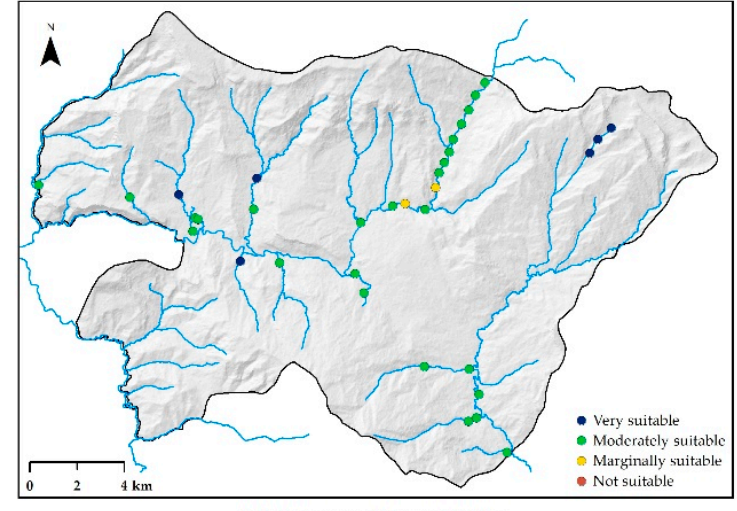

(d) Water quality suitability

Figure 5. Land suitability sub-models for small-scale aquaculture in Molinopampa. 
Table 7. Number of sampling stations (SS) of water according to suitability levels by criteria (submodel) and sub-criteria for aquaculture in Molinopampa.

\begin{tabular}{ccccccccc}
\hline \multirow{2}{*}{ Criteria/Sub-Criteria } & \multicolumn{2}{c}{ Very Suitable } & \multicolumn{2}{c}{$\begin{array}{c}\text { Moderately } \\
\text { Suitable }\end{array}$} & \multicolumn{2}{c}{$\begin{array}{c}\text { Marginally } \\
\text { Suitable }\end{array}$} & \multicolumn{2}{c}{ Not Suitable } \\
\cline { 2 - 9 } & SS & $\mathbf{\%}$ & SS & $\%$ & SS & $\%$ & SS & $\%$ \\
\hline Physicochemical quality water & 6 & 17.65 & 26 & 76.47 & 2 & 5.88 & 0 & 0.00 \\
pH & 19 & 55.88 & 3 & 8.82 & 12 & 35.29 & 0 & 0.00 \\
Dissolved oxygen (mg/L) & 31 & 91.18 & 3 & 8.82 & 0 & 0.00 & 0 & 0.00 \\
Temperature $\left({ }^{\circ} \mathrm{C}\right)$ & 4 & 11.76 & 27 & 79.41 & 3 & 8.82 & 0 & 0.00 \\
Alkalinity (ppm CaCO3) & 3 & 8.82 & 8 & 23.53 & 8 & 23.53 & 15 & 44.12 \\
Hardness (ppm CaCO3) & 17 & 50.00 & 4 & 11.76 & 7 & 20.59 & 6 & 17.65 \\
\hline
\end{tabular}

\subsection{Spatial Model Suitability for Small-Scale Aquaculture in Molinopampa}

The $4.26 \%\left(14.51 \mathrm{~km}^{2}\right)$ of the Molinopampa area proved to be "very suitable" for aquaculture (Table 8). Areas "moderately" (23.03\%) and "marginally" (69.73\%) suitable represent $92.76 \%$ of the district's total area. These locations have one or more criteria that require producers' attention and may increase the costs of pond construction and/or transport of supply and product [16]. The areas identified as restricted (Table 8 ) were road infrastructure and urban centers, and the unclassified areas were the channels and lagoons, resulting in an exclusion of $2.08 \mathrm{~km}^{2}$ from the total study area.

Table 8. Area $\left(\mathrm{km}^{2}\right)$ and land suitability percentage for aquaculture in Molinopampa.

\begin{tabular}{|c|c|c|c|c|c|c|c|c|c|c|c|c|}
\hline \multirow[t]{2}{*}{ Main Criteria } & \multicolumn{2}{|c|}{ Very Suitable } & \multicolumn{2}{|c|}{$\begin{array}{l}\text { Moderately } \\
\text { Suitable }\end{array}$} & \multicolumn{2}{|c|}{$\begin{array}{l}\text { Marginally } \\
\text { Suitable }\end{array}$} & \multicolumn{2}{|c|}{ Not Suitable } & \multicolumn{2}{|c|}{ Constraints } & \multicolumn{2}{|c|}{ Non-Classified } \\
\hline & $\mathrm{km}^{2}$ & $\%$ & $\mathrm{~km}^{2}$ & $\%$ & $\mathbf{k m}^{2}$ & $\%$ & $\mathbf{k m}^{2}$ & $\%$ & $\mathrm{~km}^{2}$ & $\%$ & $\mathrm{~km}^{2}$ & $\%$ \\
\hline Spatial suitability & 14.51 & 4.26 & 78.45 & 23.03 & 237.52 & 69.73 & 8.08 & 2.37 & 0.53 & 0.16 & 1.55 & 0.45 \\
\hline
\end{tabular}

By overlaying the water quality suitability model with the spatial suitability model (Figure 6), it reveals that two SS and nine SS are "very suitable" and "moderately suitable", respectively, coincide with lands "very suitable" for aquaculture. These are the most suitable areas for fish farming and are located in the west, center, and southeast of the study area.

\section{Discussion}

Based on the multi-study review, FAO [5,59-61] and other authors [62-64] highlight the importance of integrating RS, GIS, and MCE as a competent tool to assist in strategic decision-making for the sustainable development of aquaculture. In fact, FAO commissioned and published the first technical documents on the subject [61] in 1991 [65] and 1996 [66], and most recently in 2007 [60], 2010 [59], 2013 [61], and 2018 [5]. However, many countries with prominent aquaculture are not yet handling spatial analyses to address problems systematically and synoptically, and use GIS capabilities primarily as tools to generate map viewers [59], such as the case of Catastro's Aquaculture in Peru [27]. On the contrary, spatial methods and modern technology demonstrate that GIS capabilities, in integration with RS and MCE, go beyond management and visualization [59]. These capacities should be used for the zoning and selection of suitable sites for aquaculture development at the national level, as Uruguay [14], Colombia [15] and other countries outside South America [9,67] have done. 


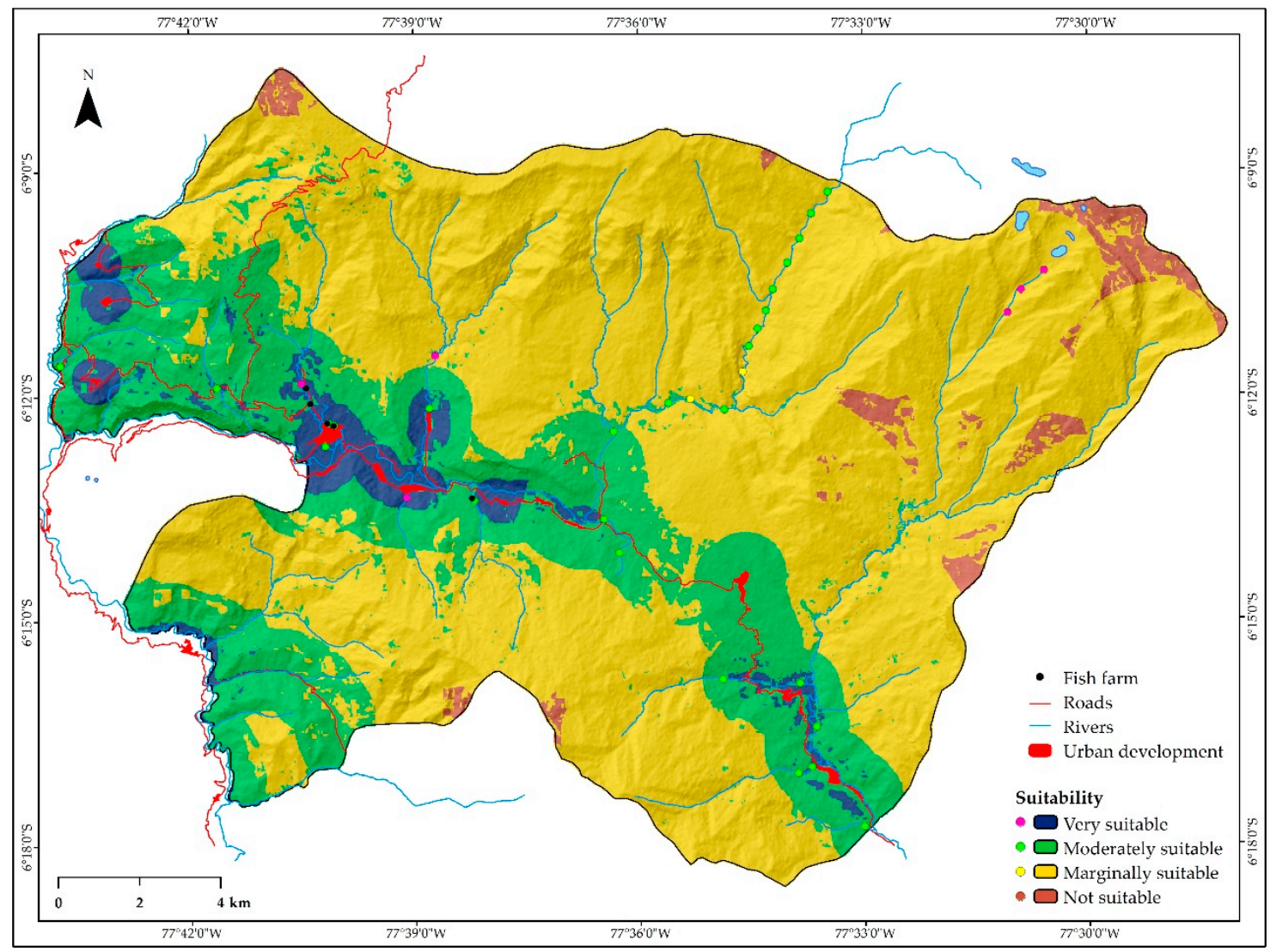

Figure 6. Land suitability map for aquaculture in Molinopampa.

The key advantages of MCE techniques are that they are well established for aquaculture zoning, they can combine multiple criteria (many more than those used in this study; [19,20,55]), and may develop models under different hierarchies, priorities, and scenarios [8]. However, the main problem in the analysis of land suitability for aquaculture in ponds dug in the soil, and in general for any activity, lies in the lack of spatial data of the criteria [16]. In Peru, and specifically in the region of Amazonas, these computing resources are scarce, even more so when it comes to specific studies of biological, environmental, and social criteria at detailed local scales. In view of this, it has been proposed to complement MCE techniques with Species Distribution Models (SDM) [8], such as Mahalanobis Typicity and MaxEnt [68]. Despite this being stated, no such approach was applied, because it depends on the georeferenced locations of the fish farms, and even though SDM such as MaxEnt has an extremely small sample size tolerance [69], it was considered inappropriate to use only the five farms, as it could affect the performance of the model. For further studies, the additional confidence that a combined approach to MCE and SDM would bring would be of vital importance for the aquaculture sector, as sustainable development depends on the planning and management decisions associated with the selection [8].

This study differs from the only two studies found to assess the land suitability for rainbow trout aquaculture $[17,18]$, in the inclusion of a greater number of criteria used, as well as the integration of an MCE (AHP) technique to rank and weight the importance of them. In contrast, it differs from other GIS and MCE-based studies for inland aquaculture in lotic water sources $[20,23,24,26]$, because it complements the spatial suitability of the land in raster model, with an assessment of the suitability of resource quality $[20,23,24,26]$, due to the fact that it complements the spatial suitability of the land in raster model with an assessment of the suitability of the quality of the water resource in a vector model. In the latter, the pixel by pixel raster weighted overlay was replaced by field calculator operations in the 
sample station point vector (SS) attribute table, which contained initial values, reclassified suitability values, and weights of the importance of each sub-criterion.

For the development of aquaculture in Molinopampa, the most important criteria are economic $(44.57 \%)$, followed by environmental (43.31\%), and social (12.12\%). According to Lobato et al. [10], Nayak et al. [20] and Hadipour et al. [70], the criterion containing the sub-criterion of distance to water sources is the most important. In Molinopampa, it is the second most important (environmental criterion), since it is a considerably favored area in water resources, with a high drainage density $\left(0.703 \mathrm{~km} / \mathrm{km}^{2}\right)$. This environmental criterion also contains the slope sub-criterion, and contrary to Rodrigues et al. [16], for whom the slope was the most important factor, in this study it holds second place. In addition to this, and after a long aquaculture experience in Amazonas, the Research Institute of the Peruvian Amazon (IIAP) indicates that the wide availability of water and the existence of terraces (inter-Andean valleys in Molinopampa) are favorable aspects for the construction and operation of fish culture ponds in the region [71].

As stated by Rodrigues et al. [16], soil texture, specifically clay content, is also an important factor, however, in this study, it is of little importance (12.88\%) because the ponds built for planting in Molinopampa are concrete. As determined by other studies, it is important to keep in mind because in very permeable soils the loss of water by filtration and infiltration could increase the water demand as well as pumping systems [72].

When it comes to the local reality of Molinopampa, the most decisive criterion was economic. Within this, the most important sub-criteria were the distance to the road network (53.49\%) and to the markets $(30.65 \%)$. The National Fisheries Development Fund of Peru (FONDEPES) recommends that the body of water selected for the development of rainbow trout farming must have vehicular access roads, which allow the fluidity of the arrival of production supplies and the output of the product towards the established markets, taking into account that the rainbow trout is highly perishable [36]. The expert group considered these sub-criteria to be the most important since Molinopampa lacks good road infrastructure, and the most prominent market (City of Chachapoyas), is an hour away, resulting in a weakness for this activity.

Of the physicochemical sub-criteria, the temperature was the most important (38.33\%) for the suitability of water quality, followed by $\mathrm{pH}(27.27 \%)$, and finally dissolved oxygen (21.59\%). In fact, FAO [37] indicates that water temperature is very important because it regulates the growth of rainbow trout, as they do not have their own capacity to regulate their body temperature. If the temperature is very low, the growth is slow, while at higher temperatures, the growth is faster. Although not specifically for rainbow trout, Nayak et al. [20] found that temperature is the most important criterion among nine physicochemical water criteria evaluated by AHP.

Finally, the climate, the wide availability of land and the plenteousness of water, coupled with the improvement of the connection with national and international markets through roads, as well as the growing markets for aquaculture, are comparative advantages of the region. These can become investment opportunities to develop aquaculture, not only as an activity aimed at meeting local market demand but also with possibilities for competitiveness in the internal and external markets, contributing to the development of region [71].

\section{Conclusions}

The ten key sub-criteria were identified and mapped to determine the spatial suitability of rainbow trout aquaculture. For Molinopampa, from highest to lowest importance, the results are as follows: the economic sub-criteria (distance to roads, distance to markets, distance to inputs) with $44.57 \%$, followed by the environmental sub-criteria (land cover/land use, land slope, clay content of soil, $\mathrm{pH}$ of soil, distance to rivers) with $43.31 \%$ and finally, the social sub-criteria (distance to populations and protected areas) with $12.12 \%$. In addition, five key sub-criteria were identified and mapped to determine the suitability of water quality, of which temperature is the most important $(38.33 \%)$, 
followed by $\mathrm{pH}(27.27 \%)$, and dissolved oxygen (21.59\%). Alkalinity (6.97\%) and hardness $(5.83 \%)$ are the least important.

The $4.26 \%\left(14.51 \mathrm{~km}^{2}\right)$ of the Molinopampa area proved "very suitable" for aquaculture. Areas "moderately suitable" (23.03\%) and "marginally suitable" (69.73\%) accounted for 92.76\% of the district's total area. "Not suitable" areas or those identified as restricted and unclassified, accounted for $2.98 \%\left(10.16 \mathrm{~km}^{2}\right)$ of the total study area. By overlaying the water quality suitability model with the spatial suitability model, it was demonstrated that two SS and nine SS are "very suitable" and "moderately suitable", respectively, which coincide with "very suitable" lands for aquaculture. These are the most suitable and recommended areas for the rainbow trout farming in the district. The results show that there is a potential to increase aquaculture production, as is the government's policy/strategy.

In Peru, no references to these types of studies have been found. Therefore, a methodological framework is presented for inland aquaculture, which may be replicated, with the necessary complements, for the entire Fisheries and Aquaculture (FandA) sector in Peru. The implementation of this methodology for zoning and selecting suitable areas will contribute to the more effective planning of investments and efforts by both the public and private sectors.

Supplementary Materials: The following are available online at http://www.mdpi.com/2220-9964/9/1/28/s1, Table S1: Paired comparison matrix to assess the relative importance of the environmental sub-criteria used to identify areas suitable for fish farming. Table S2: Paired comparison matrix to assess the relative importance of the economic sub-criteria used to identify suitable areas for fish farming. Table S3: Paired comparison matrix to assess the relative importance of the social sub-criteria used to identify suitable areas for fish farming. Table S4: Paired comparison matrix to assess the relative importance of the sub-criteria of physicochemical quality of water used to identify areas suitable for fish farming. Table S5: Paired comparison matrix to assess the relative importance of the criteria of spatial suitability used to identify suitable areas for fish farming.

Author Contributions: Conceptualization, Rolando Salas López, Elgar Barboza Castillo and Nilton B. Rojas Briceño; Data curation, Christian Ricardo Calle Yunis, Jhonsy Omar Silva López, Daniel Iliquín Trigoso and Nilton B. Rojas Briceño; Formal analysis, Nilton B. Rojas Briceño; Funding acquisition, Rolando Salas López, Segundo Manuel Oliva Cruz, Elgar Barboza Castillo and Nilton B. Rojas Briceño; Investigation, Christian Ricardo Calle Yunis, Jhonsy Omar Silva López and Daniel Iliquín Trigoso; Methodology, Christian Ricardo Calle Yunis, Rolando Salas López, Elgar Barboza Castillo and Nilton B. Rojas Briceño; Project administration, Rolando Salas López and Segundo Manuel Oliva Cruz; Resources, Segundo Manuel Oliva Cruz; Software, Nilton B. Rojas Briceño; Supervision, Rolando Salas López and Segundo Manuel Oliva Cruz; Validation, Rolando Salas López, Elgar Barboza Castillo and Nilton B. Rojas Briceño; Visualization, Rolando Salas López and Nilton B. Rojas Briceño; Writing—original draft, Christian Ricardo Calle Yunis and Daniel Iliquín Trigoso; Writing—review \& editing, Rolando Salas López, Segundo Manuel Oliva Cruz, Jhonsy Omar Silva López and Nilton B. Rojas Briceño. All authors have read and agreed to the published version of the manuscript.

Funding: This work was executed with the support of the Project "Adapting a precision technology based on biomonitoring, to improve the management of rainbow trout (Oncorhynchus mykiss) cultivation in Amazonas"-ACUIBIO; co-financed by CONTRATO No 114-2018-PNIPA-SUB-PROYECTOS by the National Agricultural Innovation Program (PNIPA) of the Ministry of Production (PRODUCE) and the SNIP Project N 312235 "Creation of the service of a Geomatics and Remote Sensing Laboratory of the Toribio Rodríguez National University, Amazonas region"-GEOMÁTICA, financed by the National Public Investment System (SNIP) of the Ministry of Economy and Finance (MEF) of Peru.

Acknowledgments: The authors acknowledge and appreciate the support of the Research Institute for the Sustainable Development of the Jungle brow zone INDES-CES of the National University Toribio Rodríguez de Mendoza (UNTRM). As well as to the group of experts, R.S.V., H.M.C., R.A.A.R., J.G.F.F., N.L.R., D.R.V.A. and the fish farmers M.J.H.R., R.C.S.C. and J.L.H.S.

Conflicts of Interest: The authors declare no conflict of interest.

\section{References}

1. Ramírez-Gastón, J. Programa Nacional de Innovación en Pesca y Acuicultura. In Taller Internacional: Experiencia Global en Gobernanza de Sistemas de Innovación en Pesca y Acuicultura; PRODUCE: Lima, Peru, 2018; pp. 14-16.

2. Ramírez-Gastón, J.; Sandoval, N.; Vicente, K. Sistema Nacional de Innovación en Pesca y Acuicultura. Fundamentos y Propuesta 2017-2022; PNIPA: Lima, Peru, 2018; p. 104.

3. PRODUCE. Anuario Estadístico Pesquero y Acuícola 2017; PRODUCE: Lima, Peru, 2018; p. 205. 
4. Saldarriaga, M.; Regalado, F. Potencial acuícola en el Perú. Moneda 2017, 172, 34-39.

5. Aguilar-Manjarrez, J.; Soto, D.; Brimmett, R. Zonificación Acuícola, Selección de Sitios y Áreas de Manejo Bajo el enfOque Ecosistémico a la Acuicultura. Un Manual; FAO, Grupo del Banco Mundial: Roma, Italia, 2018; p. 395.

6. Soto, D.; Aguilar-Manjarrez, J.; Hishamunda, N. Building an Ecosystem Approach to Aquaculture; FAO: Roma, Italy, 2008.

7. FAO. Desarrollo de la acuicultura. 4. Enfoque ecosistémico a la acuicultura. In FAO Orientaciones Técnicas Para la Pesca Responsible; FAO: Roma, Italy, 2011; Volume 5, p. 75.

8. Falconer, L.; Telfer, T.C.; Ross, L.G. Investigation of a novel approach for aquaculture site selection. J. Environ. Manag. 2016, 181, 791-804. [CrossRef] [PubMed]

9. Ross, L.G.; Telfer, T.C.; Falconer, L.; Soto, D.; Aguilar-Manjarrez, J. Site selection and carrying capacities for inland and coastal aquaculture. In FAO Fisheries and Aquaculture Proceedings; FAO: Roma, Italy, 2013; p. 295.

10. Lobato Rosales, F.G.; Martell Tamanis, A.Y.; Grosskelwing Núñez, G.; Grosskelwing Núñez, M. Enfoque metodológico para la zonificación de regiones acuícolas basado en sistemas de información geográfica. In Proceedings of the Congreso Interdisciplinario de Ingenierías, Instituto Tecnológico Superior de Misantla: Misantla, Veracruz, Mexico, November 2018; pp. 70-80.

11. Muñoz, B.; Romana, M.G.; Ordóñez, J. Análisis de Sensibilidad de una Metodología de Decisión Multicriterio desarrollada para la Selección de Tipologías de Estructuras de Contención en una Autovía Urbana. In Proceedings of the CIT2016-XII Congreso de Ingeniería del Transporte, Valencia, Spain, 1 June 2016; pp. 0-5.

12. Aguilar-Manjarrez, J.; Nath, S.S. A strategic reassessment of fish farming potential in Africa. In CIFA Technical Paper; FAO: Roma, Italy, 1998; Volume 32, p. 170.

13. Kapetsky, J.M.; Nath, S.S. A strategic assessment of the potential for freshwater fish farming in Latin America. In COPESCAL Technical Paper; FAO: Roma, Italy, 1997; Volume 10, p. 128.

14. Díaz, I.; Mello, A.L.; Salhi, M.; Spinetti, M.; Bessonart, M.; Achkar, M. Integración SIG-EMC-Análisis de agrupamiento como herramienta para la regionalización acuícola en Uruguay. Rev. Geogr. Valpso 2015, $52,14-27$.

15. Hortúa Cortés, N.G.; Merino, M.C.; Flores Nava, A. Zonificación de la Acuicultura Nacional; Autoridad Nacional de Pesca y Acuicultura (AUNAP) \& FAO: Bogotá, Colombia, 2013.

16. Rodrigues Francisco, H.; Fabrício Corrêia, A.; Feiden, A. Classification of Areas Suitable for Fish Farming Using Geotechnology and Multi-Criteria Analysis. Int. J. Geo-Inf. 2019, 8, 1-19.

17. Prasad Aryal, S.; Nath Paudel, M. GIS based potentiality of rainbow trout (Oncorhynchus mykiss) farming in northern high hill Rasuwa, Nepal. In Proceedings of the 1st National Workshop on Scaling-up of Rainbow trout (Oncorhynchus mykiss) Farming Strategies in Nepal; Bahadur Gurung, T., Ed.; Fisheries Research Division, Godawari, Lalitpur of NARC: Kathmandu, Nepal, 2008; pp. 109-114.

18. Kumar Rai, S.; Bahadur Gurung, T.; Prasad Lamsal, G. GIS based evaluation on potential sites of cold water fish, Rainbow trout (Oncorhynchus mykiss) farming in Nuwakot, Nepal. In Proceedings of the 1st National Workshop on Scaling-up of Rainbow trout (Oncorhynchus mykiss) Farming Strategies in Nepal; Bahadur Gurung, T., Ed.; Fisheries Research Division, Godawari, Lalitpur of NARC: Kathmandu, Nepal, 2008; pp. 103-108.

19. Assefa, W.W.; Abebe, W.B. GIS modeling of potentially suitable sites for aquaculture development in the Lake Tana basin, Northwest Ethiopia. Agric. Food Secur. 2018, 7, 6-15. [CrossRef]

20. Nayak, A.K.; Kumar, P.; Pant, D.; Mohanty, R.K. Land suitability modelling for enhancing fishery resource development in Central Himalayas (India) using GIS and multi-criteria evaluation approach. Aquac. Eng. 2018, 83, 120-129. [CrossRef]

21. Ebaid, H.M.; Abou, E.E.S.M. Mapping of Aquaculture in River Nile Using Google Earth Images and GIS Procedures-Rosetta Branch, Egypt. J. Am. Sci. 2017, 13, 57-63.

22. Hasim; Koniyo, Y.; Kasim, F. Suitable location map of floating net cage for environmentally friendly fish farming development with geographic information systems applications in lake Limboto, Gorontalo, Indonesia. AACL Bioflux 2017, 10, 254-264.

23. Ramadhini, M.; Rikardo, A. Utilization of Geographic Information System (GIS) in Determining the Suitability of Fisheries Locations Cultivation of Freshwater Fish Ponds in South Aceh Regency. J. Inov. Teknol. Dan Rekayasa 2018, 3, 81-86. [CrossRef] 
24. Mustafa, F.-B.; Bwadi, B.E. Determination of Optimal Freshwater Prawn Farming Site Locations using GIS and Multicriteria Evaluation. J. Coast. Res. 2018, 82, 41-54. [CrossRef]

25. Ssegane, H.; Tollner, E.W.; Veverica, K. Geospatial Modeling of Site Suitability for Pond-Based Tilapia and Clarias Farming in Uganda. J. Appl. Aquac. 2012, 24, 147-169. [CrossRef]

26. Völcker, C.M.; Scott, P. SIG e sensoriamento remoto para a determinação do potencial para aqüicultura no baixo São João-RJ. Rev. Eletrônica Sist. Gestão 2008, 3, 196-215.

27. PRODUCE. Catastro Acuicola Nacional. Available online: http://catastroacuicola.produce.gob.pe (accessed on 28 October 2019).

28. Vargas Rivera, J. Clima. In Estudios temáticos para la Zonificación Ecológica Económica del departamento de Amazonas; Instituto de Investigaciones de la Amazonía Peruana (IIAP) \& Programa de Investigaciones en Cambio Climático, Desarrollo Territorial y Ambiente (PROTERRA): Chachapoyas, Peru, 2010; pp. 1-27.

29. INEI. Resultados definitivos de los Censos Nacionales 2017: Amazonas. In Censos Nacionales 2017: XII de Población, VII de Vivienda y III de Comunidades Indígenas; INEI: Lima, Peru, 2017; pp. 1-11347.

30. Ramírez Barco, J.M. Uso actual de la tierra. In Estudios temáticos para la Zonificación Ecológica Económica del departamento de Amazonas; Instituto de Investigaciones de la Amazonía Peruana (IIAP) \& Programa de Investigaciones en Cambio Climático, Desarrollo Territorial y Ambiente (PROTERRA): Chachapoyas, Peru, 2010; pp. 1-39.

31. Oliva Cruz, S.M.; Collazos Silva, R.; Goñas Más, M.; Bacalla, E.; Vigo Mestanza, C.; Vásquez Pérez, H.; Espinosa Leiva, S.T.; Maicelo Quintana, J.L. Efecto de los sistemas de producción sobre las características físico-químicas de los suelos del distrito de Molinopampa, provincia de Chachapoyas, región Amazonas. Rev. Indes 2014, 2, 44-52.

32. Oliva, M.; Vacalla, F.; Pérez, D.; Tucto, A. Vivero Forestal Para la Producción de Plantones de Especies Forestales Nativas: Experinecia en Molinopampa, Amazonas-Perú; IIAP, MINAGRI, SERFOR \& OIMT: Chachapoyas, Peru, 2014; pp. 1-20.

33. Oliva Cruz, S.M. Influencia de factores socioeconómicos y ambientales sobre la adopción de tecnologías silvopastoriles por productores ganaderos, distrito de Molinopampa, Amazonas, Perú. Master's Thesis, Universidad Nacional Agraria La Molina, Lima, Peru, 2016.

34. MINAM. Resolución Ministerial No 252-2012-MINAM; MINAM: Lima, Peru, 2012; p. 9. Available online: http:// www.minam.gob.pe/disposiciones/resolucion-ministerial-n-252-2012-minam/ (accessed on 28 October 2019).

35. PRODUCE. GEOSNIPA: Geovisor PNIPA. Available online: http://cdi.pnipa.gob.pe/geosnipa/ (accessed on 2 November 2019).

36. FONDEPES. Manual de Crianza de Trucha en Ambientes Convencionales; PRODUCE: Lima, Peru, 2014; p. 88.

37. FAO. Manual Práctico Para el Cultivo de la Trucha Arcoíris; FAO: Guatemala, 2014; p. 44.

38. Prakash Maurya, S.; Ohri, A.; Mishra, S. Open Source GIS: A Review. In Proceedings of the National Conference on Open Source GIS: Opportunities and Challenges, Varanasi, India, 9-10 October 2015; Department of Civil Engineering, Indian Institute of Technology (BHU): Varanasi, India, 2015; pp. 150-155.

39. Farr, T.G.; Rosen, P.A.; Caro, E.; Crippen, R.; Duren, R.; Hensley, S.; Kobrick, M.; Paller, M.; Rodriguez, E.; Roth, L.; et al. The Shuttle Radar Topography Mission. Rev. Geophys. 2007, 45, 1-33. [CrossRef]

40. Congedo, L. Semi-Automatic Classification Plugin for QGIS.; Sapienza University: Roma, Italy, 2013; p. 25.

41. Rojas Briceño, N.B.; Barboza Castillo, E.; Maicelo Quintana, J.L.; Oliva Cruz, S.M.; Salas López, R. Deforestación en la Amazonía peruana: Índices de cambios de cobertura y uso del suelo basado en SIG. BAGE 2019, 81, 1-34. [CrossRef]

42. MINAM. Mapa Nacional de Cobertura Vegetal. Memoria Descriptiva; Ministerio del Ambiente, Dirección General de Evaluación, Valoración y Financiamiento del Patrimonio Natural: Lima, Peru, 2015; p. 108.

43. Landis, J.R.; Koch, G.G. An Application of Hierarchical Kappa-type Statistics in the Assessment of Majority Agreement among Multiple Observers. Biometrics 1977, 33, 363-374. [CrossRef]

44. Chuvieco, E. Fundamentals of Satellite Remote Sensing. An Enviromental Approach, 2nd ed.; CRC Press Taylor \& Francis Group: New York, NY, USA, 2016.

45. MTC. Descarga de Datos Espaciales. Available online: https://portal.mtc.gob.pe/estadisticas/descarga.html (accessed on 15 April 2019).

46. MINEDU. Descarga de Información Espacial del MED. Available online: http://sigmed.minedu.gob.pe/ descargas/ (accessed on 15 April 2019). 
47. Gilvear, D.J.; Hunter, P.; Stewardson, M. Remote Sensing: Mapping Natural and Managed River Corridors from the Micro to the Network Scale. In River Science: Research and Management for the 21st Century; Gilvear, D.J., Greenwood, M.T., Thoms, M.C., Wood, P.J., Eds.; John Wiley \& Sons, Ltd.: Chennai, India, 2016; pp. 171-196.

48. Large, A.R.G.; Gilvear, D.J. Using Google Earth, A Virtual-Globe Imaging Platform, for Ecosystem Services-Based River Assessment. River Res. Appl. 2014, 7, 1-16.

49. Hengl, T.; De Jesus, J.M.; Heuvelink, G.B.M.; Gonzalez, M.R.; Kilibarda, M.; Blagotić, A.; Shangguan, W.; Wright, M.N.; Geng, X.; Bauer-Marschallinger, B.; et al. SoilGrids250m: Global gridded soil information based on machine learning. PLoS ONE 2017, 12, 1-40. [CrossRef]

50. SERNANP. Servicio Nacional de Áreas Naturales Protegidas por el Estado. Servicios y Recursos. Available online: https://www.geoidep.gob.pe/servicio-nacional-de-areas-naturales-protegidas-por-elestado (accessed on 15 April 2019).

51. Saaty, T.L. Fundamentals ofthe Analytie Hierarehy Process. In The Anal ytic Hierarchy Process in Natural Resource and Environmental Decision Making; Schmoldt, D.L., Kangas, J., Mendoza, G.A., Pesonen, M., Eds.; Springer-Science+Business Media: Berlin/Heidelberg, Germany, 2001; pp. 15-36.

52. Mighty, M.A. Site suitability and the analytic hierarchy process: How GIS analysis can improve the competitive advantage of the Jamaican coffee industry. Appl. Geogr. 2015, 58, 84-93. [CrossRef]

53. Saaty, T.L. A scaling method for priorities in hierarchical structures. J. Math. Psychol. 1977, 15, $234-281$. [CrossRef]

54. Aldababseh, A.; Temimi, M.; Maghelal, P.; Branch, O.; Wulfmeyer, V. Multi-criteria evaluation of irrigated agriculture suitability to achieve food security in an arid environment. Sustainability 2018, 10, 803. [CrossRef]

55. Hossain, M.S.; Das, N.G. GIS-based multi-criteria evaluation to land suitability modelling for giant prawn (Macrobrachium rosenbergii) farming in Companigonj Upazila of Noakhali, Bangladesh. Comput. Electron. Agric. 2010, 70, 172-186. [CrossRef]

56. Saaty, T.L. How to make a decision: The Analytic Hierarchy Process. Eur. J. Oper. Res. 1990, 48, 9-26. [CrossRef]

57. Mu, E.; Pereyra-Rojas, M. Understanding the Analytic Hierarchy Process. In Practical Decision Making; SpringerBriefs in Operations Research: Berlin, Germany, 2017; pp. 7-22.

58. Aguarón, J.; Moreno-Jiménez, J.M. The geometric consistency index: Approximated thresholds. Eur. J. Oper. Res. 2003, 147, 137-145. [CrossRef]

59. Aguilar-Manjarrez, J.; Kapetsky, J.M.; Soto, D. The potential of spatial planning tools to support the ecosytem approach to aquaculture. In FAO Fisheries and Aquaculture Proceedings; FAO: Roma, Italy, 2010; Volume 17, p. 185.

60. Kapetsky, J.M.; Aguilar-Manjarrez, J. Geographic information systems, remote sensing and mapping for the development and management of marine aquaculture. In FAO Fisheries Technical Paper; FAO: Roma, Italy, 2007; Volume 458, p. 141.

61. Meaden, G.J.; Aguilar-Manjarrez, J. Advances in geographic information systems and remote sensing for fisheries and aquaculture. In FAO Fisheries and Aquaculture Proceedings; FAO: Roma, Italy, 2013; Volume 552, p. 111.

62. Ottinger, M.; Clauss, K.; Kuenzer, C. Aquaculture: Relevance, distribution, impacts and spatial assessments-A review. Ocean Coast. Manag. 2016, 119, 244-266. [CrossRef]

63. Nath, S.S.; Bolte, J.P.; Ross, L.G.; Aguilar-manjarrez, J. Applications of geographical information systems (GIS) for spatial decision support in aquaculture. Aquac. Eng. 2000, 23, 233-278. [CrossRef]

64. Falconer, L.; Middelboe, A.L.; Kaas, H.; Ross, L.G.; Telfer, T.C. Use of geographic information systems for aquaculture and recommendations for development of spatial tools. Rev. Aquac. 2019, 17, 1-14. [CrossRef]

65. Meaden, G.J.; Kapetsky, J.M. Geographical information systems and remote sensing in inland fisheries and aquaculture. FAO Fisheries Technical Paper; FAO: Roma, Italy, 1991; Volume 318, p. 262.

66. Meaden, G.J.; Do Chi, T. Geographical information systems Applications to marine fisheries. In FAO Fisheries Technical Paper; FAO: Roma, Italy, 1996; Volume 356, p. 335.

67. Grimshaw, T. Draft-National Aquaculture Zoning Plan For Belize; Tunich-Nah Consultants \& Engineering: Belize City, Belize, 2003; p. 216.

68. Phillips, S.J.; Anderson, R.P.; Schapire, R.E. Maximum entropy modeling of species geographic distributions. Ecol. Model. 2006, 190, 231-252. [CrossRef] 
69. Merow, C.; Smith, M.J.; Silander, J.A. A practical guide to MaxEnt for modeling species' distributions: What it does, and why inputs and settings matter. Ecography 2013, 36, 1058-1069. [CrossRef]

70. Hadipour, A.; Vafaie, F.; Hadipour, V. Land suitability evaluation for brackish water aquaculture development in coastal area of Hormozgan, Iran. Aquac. Int. 2014, 23, 329-343. [CrossRef]

71. Alcántara Bocanegra, F.; Rodríguez Chu, L.; Marie Cuq, A.; Tello Martín, S.; Del Castillo Torres, D. Avances en el desarrollo de la acuicultura en la región Amazonas, Perú; IIAP: Iquitos, Peru, 2007; p. 49.

72. Hossain, M.S.; Chowdhury, S.R.; Das, N.G.; Rahaman, M.M. Multi-criteria evaluation approach to GIS-based land-suitability classification for tilapia farming in Bangladesh. Aquac. Int. 2007, 15, 425-443. [CrossRef] 